\title{
Modeling of a Pressurized Entrained-Flow Coal Gasifier for Power Plant Simulation
}

\author{
Author: Dr.-Ing. M. Krüger \\ DLR (German Aerospace Centre), Institute of Technical Thermodynamics, \\ Pfaffenwaldring 38-40, 70569 Stuttgart, Germany \\ E-mail: michael.krueger@dlr.de
}

\begin{abstract}
Now and in the mid-term future, coal remains an important energy source for electricity generation for reasons of energy supply security and economics. The expectation to get low $\mathrm{CO}_{2}$-emissions and high plant efficiencies, particularly independently of coal quality, makes coal gasification an essential part of numerous innovative power plant concepts. For that reason, simplified and flexible models for coal gasifiers are needed, which can be implemented easily in complex power plant system simulations. A model for an entrained-flow coal gasifier, the Prenflo coal gasification process, based on an equilibrium approach is developed. The created model is validated with operation data published in literature of a demonstration plant in Fürstenhausen (Germany). For all published plant parameters, the calculated values of the model reproduce the operating data fairly precisely. Parametric study for the target application in a hybrid power plant including high temperature fuel cells regarding the gasification temperature and pressure as well as the mass flow ratios of the gasifying agent to coal is presented. Influences of these parameters on the product gas composition and efficiency of gasification are investigated. By means of these, the model of the coal gasifier is qualified for implementation in system models such as those of integrated gasification combined cycle and hybrid power plants including high temperature fuel cells.
\end{abstract}

Keywords: Modeling; Prenflo; coal gasifier; coal gasification; IGCC; IGFC; hybrid power plant.

\section{Introduction}

In order to satisfy the permanently increasing energy demand worldwide the combination of different energy sources needs to be utilized. Fossil energy sources contribute approx. $80 \%$ to the worldwide energy supply, whereas about a quarter of it is gained from coal. The International Energy Agency (IEA) predicts a $50 \%$ increase of coal consumption by 2030. On the one hand, this is caused by the huge worldwide available resources of coal and by the advanced development of coal-fired power plants on the other. Coal is regarded as an important energy source for electricity generation for supply security as well as economic reasons

The combustion of fossil energy carriers is one of the main sources of $\mathrm{CO}_{2}$-emissions. Increasing the $\mathrm{CO}_{2-}$ concentration in the atmosphere accelerates the greenhouse effect, which is commonly considered to be the main reason for climate change. Numerous international agreements and letters of intent were decided to prevent climate change, and to reduce its consequences respectively, by reducing $\mathrm{CO}_{2-}$ emissions significantly. For complying with existing agreements and guidelines, the following approaches can be productive:

- reduction of energy use,

- increasing the $\mathrm{CO}_{2}$-sinks,

- usage of less carbonaceous, carbon free or renewable energy carriers,

- improving efficiency of power generation,

- $\mathrm{CO}_{2}$-sequestration.

The global power plant sector share of $\mathrm{CO}_{2}$-emissions is about $40 \%$. For reducing these emissions, the last three options can be used by electricity producers; if coal as fuel is fixed, just the latter two. For increasing efficiency and introduction of $\mathrm{CO}_{2}$-sequestration into market, the optimization or retrofitting of existing power plants as well as the development of innovative power plant concepts are necessary to survive on the market in mid- to long-term. For the conception of new coal-fired power plants with improved overall efficiency and optional $\mathrm{CO}_{2-}$ sequestration, the technology of coal gasification becomes increasingly important. Examples are integrated gasification combined cycles (IGCC) for electricity generation or polygeneration and innovative hybrid power plants including high temperature fuel cells, such as developed in [1] and [2]. These plants are very complex due to a high level of thermal and material integration.

For their simulation, simplified process models are therefore needed, which would allow the flexibility in operating conditions and parametric studies. At the same time, the requirement to reproduce the operating characteristics of installed plants at a sufficiently high model accuracy has to be fulfilled.

\section{Fundamentals of Coal Gasification}

Gasification in a technical sense is defined as thermochemical conversion of carbon-based fuels together with gasifying agents at temperatures above $700{ }^{\circ} \mathrm{C}$ to produce gases with combustible and, respectively, reductive gas components [3], [4]. The objective hereby is to gasify as complete and efficient as possible and to achieve a defined product gas composition, at the same time.

The energetic performance of gasification processes is evaluated by the degree of coal conversion, cold gas 
efficiency and thermal efficiency [5]. The degree of coal conversion $\eta_{G, C G}$ indicates how much of the introduced amount of carbon is converted in the gasifier, and is defined in Eq. (1) [6].

$$
\eta_{C, C G}=1-\frac{\dot{m}_{R G} w_{C, R G}}{\dot{m}_{C} w_{C, C}}
$$

where $\dot{m}_{R G}$ is mass flow of the raw gas, $w_{C, R G}$ is the mass portion of carbon in raw gas, $\dot{m}_{C}$ is mass flow of coal, and $w_{C, C}$ is mass portion of carbon in coal.

The cold gas efficiency $\eta_{C G, C G}$ describes how much of chemically bound energy is in the product gas compared to the feed coal. It is defined in Eq. (2) with regard to the net calorific value [5].

$\eta_{C G, C G}=\frac{\dot{m}_{R G} N C V_{R G}}{\dot{m}_{C} N C V_{C}}$

where $N C V_{R G}$ is the net calorific value of raw gas, and $N C V_{C}$ is the net calorific value of coal.

To set up the thermal efficiency, a comprehensive energy balance of the coal gasifier is generated. Besides chemically bound energy, the sensible heat of incoming and outgoing streams and heat output by cooling of the gasifier are taken into account. The thermal efficiency $\eta_{t h, C G}$ is defined in Eq. (3) [5]. The difference to the value of 1 is due to the heat losses through the walls of the gasifier and the remove of slag.

$$
\eta_{t h, C G}=\frac{\dot{m}_{R G}\left(h_{R G}+N C V_{R G}\right)+\dot{Q}_{o u t}}{\dot{m}_{C}\left(h_{C}+N C V_{C}\right)+\dot{m}_{G A} h_{G A}}
$$

where $h_{R G}$ is the specific enthalpy of the raw gas, $\dot{Q}_{\text {out }}$ is the heat output by cooling of the gasifier, $h_{C}$ is the specific enthalpy of the coal, $\dot{m}_{G A}$ is the mass flow gasifying agent, and $h_{G A}$ is the specific enthalpy of gasifying agent.

\section{The Prenflo Coal Gasification Process}

Many variants of gasifiers have been developed; here just the Prenflo (Pressurised Entrained Flow) [7] coal gasification process will be briefly described. The process was tested extensively in a power plant in Fürstenhausen (Saarland, Germany) and is still in operation as a largescale plant in the IGCC of Puertollano (Spain). Main application areas of the Prenflo process are seen in electricity generation [8]. It provides very high degrees of coal conversion and very low tar portions in the syngas; the values of cold gas efficiency and thermal efficiency satisfy current state-of-the-art standards. For all the abovementioned reasons, this established process is used in the present article and is considered by the author as suitable for the usage in such hybrid power plants as presented in [1] and [2].

The Prenflo coal gasification process is a pressurized entrained-flow gasifier from the Uhde $\mathrm{GmbH}$, which operates autothermic and in direct current flow. All types of coal can be gasified, whereas the coal input has to be dry or with a moisture content lower than 1-2 wt \% and in the form of coal dust with a particle size distribution in which $90 \%$ of particles are smaller than $1 \mathrm{~mm}$ [8]. The coal dust is transported with nitrogen as the carrier gas to the gasifier through a system of locks and delivered to the lower part of the reactor with oxygen and steam through four burners arranged in the same plane, see Figure 1. The reactor has a cooled refractory lining, because the flame temperatures above $2000{ }^{\circ} \mathrm{C}$ can appear during gasification [8]. The operating pressure is between 24 and 30 bar [9], whereby the exact level depends on the downstream process stage requirements. Due to the high temperature level, the ash content of coal is molten for the most part and flows down the reactor walls, where it is granulated in a water bath and brought out of the gasifier via a system of locks. The granulated inert slag is practically free of carbon.

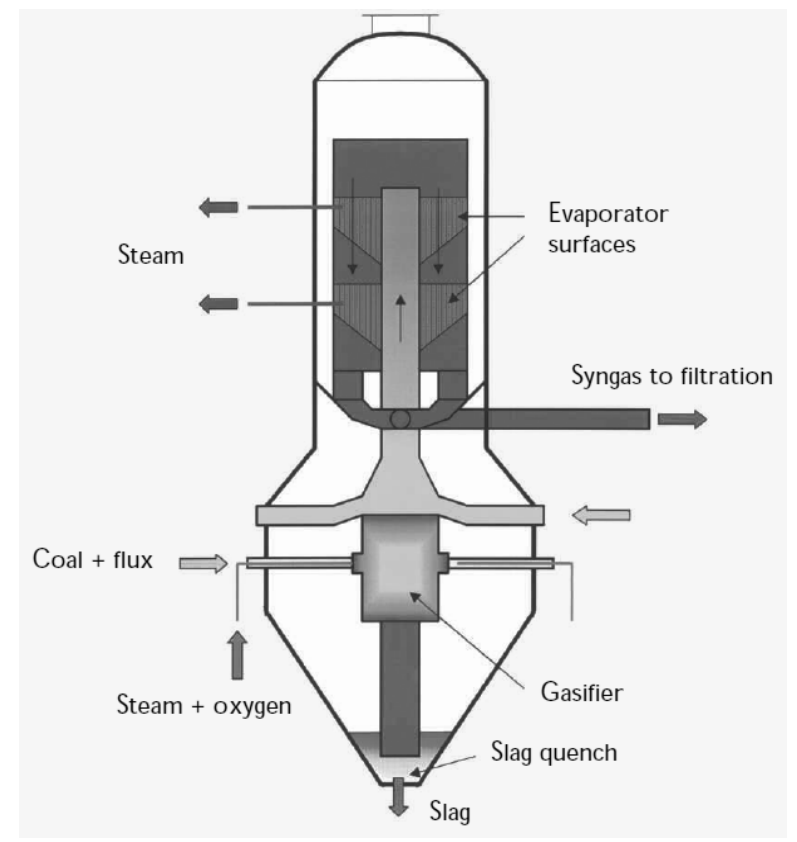

Figure 1. Scheme of the Prenflo entrained-flow gasifier according to [10].

The raw gas produced in the reactor leaves at the top with temperatures in the range of $1350-1600{ }^{\circ} \mathrm{C}$ [8]. To prevent leakage of molten ash, the raw gas is quenched. There are two main methods: quenching with water and quenching with cooled clean gas. Only the last one is used for syngases in the electricity sector [11]. Here, the syngas is quenched with recycled clean syngas to reach a temperature of approx. $800{ }^{\circ} \mathrm{C}$ [10]. After this, it flows up in a central distributor pipe and down again, passing evaporator surfaces before leaving the gasifier with temperature around $400{ }^{\circ} \mathrm{C}$ [10]. The design of the Prenflo gasifier differs from other entrained-flow gasifiers, because not only the actual gasifier but also the syngas cooler are arranged in the same containment.

Together with the raw gas, a part of the coal ash leaves the gasifier as flue dust. This is separated in a downstream process stage and recycled to the gasifier.

Due to the high operating temperature, the raw gas produced within the Prenflo-gasifier consists mainly of carbon monoxide and hydrogen; byproducts are carbon dioxide, nitrogen, argon, hydrogen sulfide, carbonyl sulfide and hydrogen chloride. Methane is one of the numerous trace elements - other hydrocarbons such as tar and phenols are not produced, neither are nitrogen oxides. The net calorific value of the raw gas depends on the specific coal and amounts to approx. $11 \mathrm{MJ} / \mathrm{Nm}^{3}$ (wf). [12]

The degree of coal conversion according to Eq. (1) is greater than $99 \%$ if the recycling of coal particles carried 
back to the gasifier is taken into account. Cold gas efficiency according to Eq. (2) is about $81 \%$, thermal efficiency according to Eq. (3) is approx. $95 \%$. [12]

\section{Modeling of Coal Gasifiers in Literature}

The general objective of modeling a coal gasifier is to predict and interpret its operating characteristics. This includes, among others, the product gas composition, needed resource requirements, the degree of resulting efficiency and the existing behavior to load changes. They are influenced by such coal characteristics as reactivity, proximate and ultimate analysis, as well as design and operating parameters such as gasifier size, pressure and composition of the gasifying agent. The level of detail and complexity of the models depends on the gasifier type and desired use. [13]

The following model types for the reproduction of coal gasifiers are most common [13]:

- Black box models use empirical correlations based on experimental data. These equations are approximations or interpolations and generally do not reflect the physical principles behind the dependences.

- Equilibrium models enable the calculation of product gas composition, degree of coal conversion, efficiencies and conditions at the reactor outlet. Since chemical equilibrium is reached complete only after a long time, equilibrium models are always approximations of an actual state. They are very common for modeling high temperature gasification systems as entrained-flow or molten bath gasifiers, where chemical reactions reach state of equilibrium quickly.

- Kinetic models are used to describe the local conditions in chemical reactors. Mathematical description is based on spatially resolved mass and energy balances, which finally leads to systems of differential equations.

Here, a gasifier model is needed which describes the mass and energetic balances sufficiently correctly, on the one hand, and meets the requirements regarding short computing time and high flexibility for use in power plant simulations on the other. Equilibrium models fulfill these conditions, particularly in case of entrained-flow gasifiers. This is a view generally shared by literature, inter alia [1417].

There are many examples of equilibrium models of entrained-flow coal gasifiers in literature. They can be distinguished in modified and fully equilibrium models.

In modified equilibrium models, some parameters of equilibrium calculation as a reaction rate or equilibrium temperature of some or all chemical reactions are adapted to adjust the calculated results to experimental data. These data generally do not correlate with property values of feed coal or operating conditions of gasifier. Therefore, these models are only precise in a small range. Examples for modified equilibrium models are [5], [15] and [17-22].

In fully equilibrium models, the Gibbs energy minimization method is used in an unmodified manner. Examples are [23-31]. In [23-26] the Prenflo gasifier is used. Kovacik et al. [26] are the only ones who validated their model with experimental data. Kovacik et al. modeled the reaction chamber exclusively without consideration of the in-situ energy management of the Prenflo process described in Chapter 3.

As far as the author knows, a validated model of the overall Prenflo gasification process using unmodified Gibbs energy minimization method have not yet been published.

\section{Created Model of a Pressurized Entrained-Flow Coal Gasifier}

In the model created here, the entrained-flow gasifier is considered an isothermal reactor. Raw gas composition at the gasifier outlet is the result of a simultaneous equilibrium in all reactions taking place. All energetic main and side reactions are considered by the model; chemical intermediates as tars and phenols and formation of trace elements are neglected. Coal ash is assumed an inert component with unknown composition. The main reactions of coal gasification with enthalpy of reactions are listed in Table 1. Most of them are partial oxidation processes, with oxygen in free or in carbon dioxide or water bounded form [14].

Table 1. Main Reactions of Coal Gasification from [32]; Selected Independent Key Reactions are Shaded Gray.

\begin{tabular}{c|c|c}
\hline Partial combustion & $\mathrm{C}+1 / 2 \mathrm{O}_{2} \Leftrightarrow \mathrm{CO}$ & $\Delta^{R} H=-111 \mathrm{~kJ} / \mathrm{mol}$ \\
\hline Combustion & $\mathrm{C}+\mathrm{O}_{2} \Leftrightarrow \mathrm{CO}_{2}$ & $\Delta^{R} H=-406 \mathrm{~kJ} / \mathrm{mol}$ \\
\hline Water generation & $\mathrm{H}_{2}+1 / 2 \mathrm{O}_{2} \Leftrightarrow \mathrm{H}_{2} \mathrm{O}$ & $\Delta^{R} H=-242 \mathrm{~kJ} / \mathrm{mol}$ \\
\hline $\begin{array}{c}\text { Boudouard } \\
\text { reaction }\end{array}$ & $\mathrm{C}+\mathrm{CO}_{2} \Leftrightarrow 2 \mathrm{CO}$ & $\Delta^{R} H=+162 \mathrm{~kJ} / \mathrm{mol}$ \\
\hline $\begin{array}{c}\text { Heterogeneous } \\
\text { water gas reaction }\end{array}$ & $\mathrm{C}+\mathrm{H}_{2} \mathrm{O} \Leftrightarrow \mathrm{CO}+\mathrm{H}_{2}$ & $\Delta^{R} H=+119 \mathrm{~kJ} / \mathrm{mol}$ \\
\hline Hydrogasification & $\mathrm{C}+2 \mathrm{H}_{2} \Leftrightarrow \mathrm{CH}_{4}$ & $\Delta^{R} H=-87 \mathrm{~kJ} / \mathrm{mol}$ \\
\hline Methanization & $\mathrm{CO}+3 \mathrm{H}_{2} \Leftrightarrow \mathrm{CH}_{4}+\mathrm{H}_{2} \mathrm{O}$ & $\Delta^{R} H=-206 \mathrm{~kJ} / \mathrm{mol}$ \\
\hline $\begin{array}{c}\text { Homogeneous } \\
\text { water gas reaction }\end{array}$ & $\mathrm{CO}+\mathrm{H}_{2} \mathrm{O} \Leftrightarrow \mathrm{CO}_{2}+\mathrm{H}_{2}$ & $\Delta^{R} H=-41 \mathrm{~kJ} / \mathrm{mol}$ \\
\hline
\end{tabular}

These equations include seven components, namely $\mathrm{C}$, $\mathrm{CO}, \mathrm{CO}_{2}, \mathrm{CH}_{4}, \mathrm{H}_{2} \mathrm{O}, \mathrm{O}_{2}$ and $\mathrm{H}_{2}$, which consist of the three elements $\mathrm{C}, \mathrm{O}$ and $\mathrm{H}$. From this follows that 7-3=4 key reactions are required to calculate the equilibrium composition. Sets of independent key reactions can be built from the mapped reactions. Here, the set of key reactions consisting of partial combustion, hydrogasification, heterogeneous and homogeneous water gas reactions are used. [33]

Other main components of coal according to an ultimate analysis from Table 3 are sulfur, nitrogen and chlorine. These components react inside the reactor via side reactions listed in Table 2. They are less relevant for the energy balance of the reactor, but crucial for the formation of environmental and climate relevant pollutants.

Table 2. Relevant Side Reactions of Coal Gasification from [5].

\begin{tabular}{c|c|c}
\hline $\begin{array}{c}\text { Formation of } \\
\text { hydrogensulfide }\end{array}$ & $\mathrm{S}+\mathrm{H}_{2} \Leftrightarrow \mathrm{H}_{2} \mathrm{~S}$ & $\Delta^{R} H=-21 \mathrm{~kJ} / \mathrm{mol}$ \\
\hline $\begin{array}{c}\text { Formation of } \\
\text { carbonyl sulfide }\end{array}$ & $\mathrm{S}+\mathrm{CO} \Leftrightarrow \mathrm{COS}$ & $\Delta^{R} H=-32 \mathrm{~kJ} / \mathrm{mol}$ \\
\hline $\begin{array}{c}\text { Formation of } \\
\text { ammonia }\end{array}$ & $\mathrm{N}_{2}+3 \mathrm{H}_{2} \Leftrightarrow 2 \mathrm{NH}_{3}$ & $\Delta^{R} H=-92 \mathrm{~kJ} / \mathrm{mol}$ \\
\hline $\begin{array}{c}\text { Formation of } \\
\text { hydrocyanic acid }\end{array}$ & $\begin{array}{c}\mathrm{N}_{2}+\mathrm{H}_{2} \mathrm{O}+2 \mathrm{CO} \Leftrightarrow \\
2 \mathrm{HCN}^{2} 3 / 2 \mathrm{O}_{2}\end{array}$ & $\Delta^{R} H=+733 \mathrm{~kJ} / \mathrm{mol}$ \\
\hline $\begin{array}{c}\text { Formation of } \\
\text { hydrogen chloride }\end{array}$ & $\mathrm{Cl}_{2}+\mathrm{H}_{2} \Leftrightarrow 2 \mathrm{HCl}$ & $\Delta^{R} H=-92 \mathrm{~kJ} / \mathrm{mol}$ \\
\hline
\end{tabular}


Thermodynamic equilibrium of isothermal and isobaric systems can be calculated based on the well known Gibbs energy minimization method.

The implementation of the model of an entrained-flow gasifier in process modeling environment Aspen Plus ${ }^{\mathrm{TM}}$ Version 2006.5 is based on example simulation of coal combustion [34] and publications by Kloster [5] and Korobov [35]. The resulting simulation flowchart of coal gasification with upstream coal drying is illustrated in Figure 2. Coal drying and pulverizing facilities are not modeled in detail but balanced energetically.

Relevant input parameters are pressure, temperature, composition of feed coal according Table 3 and gross calorific value of the coal on a dry basis.

Before the coal is converted into gas, it has to be dried. It is assumed that pure nitrogen delivered from an air separation unit is used for drying. The heat required for the drying process can be extracted from a water/steam cycle, for instance. The water proportion to be separated from coal is defined in a FORTRAN based user subroutine (Calculator - Aspen Plus ${ }^{\mathrm{TM}}$ names are written in italics and are described in [34]) and is transfered from solid to gas phase in a stoichiometric reactor (RStoic). At this point the pure nitrogen is supplied. The amount of heat needed to evaporate the separated water is calculated with the help of a Heater and can be optionally removed from heat balancing of the water/steam cycle. The actual separation of evaporated water takes place afterwards in a nonphysical knockout drum (Flash2-separator), where the coal flow is degassed.
The dry coal is delivered to the reactor by carrier nitrogen from an air separation unit. The level of pressure and temperature of the carrier nitrogen is determined by the air separation unit; for adjusting the mass flow - which can be gotten from clean gas composition published in [36] to $0.08516 \mathrm{~kg} / \mathrm{s}$ nitrogen for $1 \mathrm{~kg} / \mathrm{s}$ dry coal - a feedback control system (Design Spec) is used.

The gasification reactor itself consists of several standard built-in components of the process simulation software. At first, coal is decomposed into its elementary composition by a yield reactor with known product yield (RYield-reactor). Heat required for this is delivered by a downstream multiphase chemical equilibrium reactor (RGibbs-reactor), which represents the actual coal gasification reactor. Here, the syngas is generated at given constant values of temperature and pressure by usage of oxygen and steam as gasifying agents. Composition of the syngas results from calculation of simultaneous equilibrium of all reactions listed in Tables 1 and 2. Pressure and temperature of gasifying agents are predefined by the delivering subsystems. These are the air separation unit in the case of oxygen and the water/steam cycle in the case of steam. The mass flow of the gasifying agents is defined by the mass flow ratios from the gasifying agent to coal. These were determined by Orlandi [37] and amounted to $1.0687 \mathrm{~kg} / \mathrm{s}$ oxygen and $0.1579 \mathrm{~kg} / \mathrm{s}$ steam for $1 \mathrm{~kg} / \mathrm{s}$ water and ash free coal. These ratios are adjusted within a feedback control system (Design Spec) by varying the mass flows of the gasifying agents.

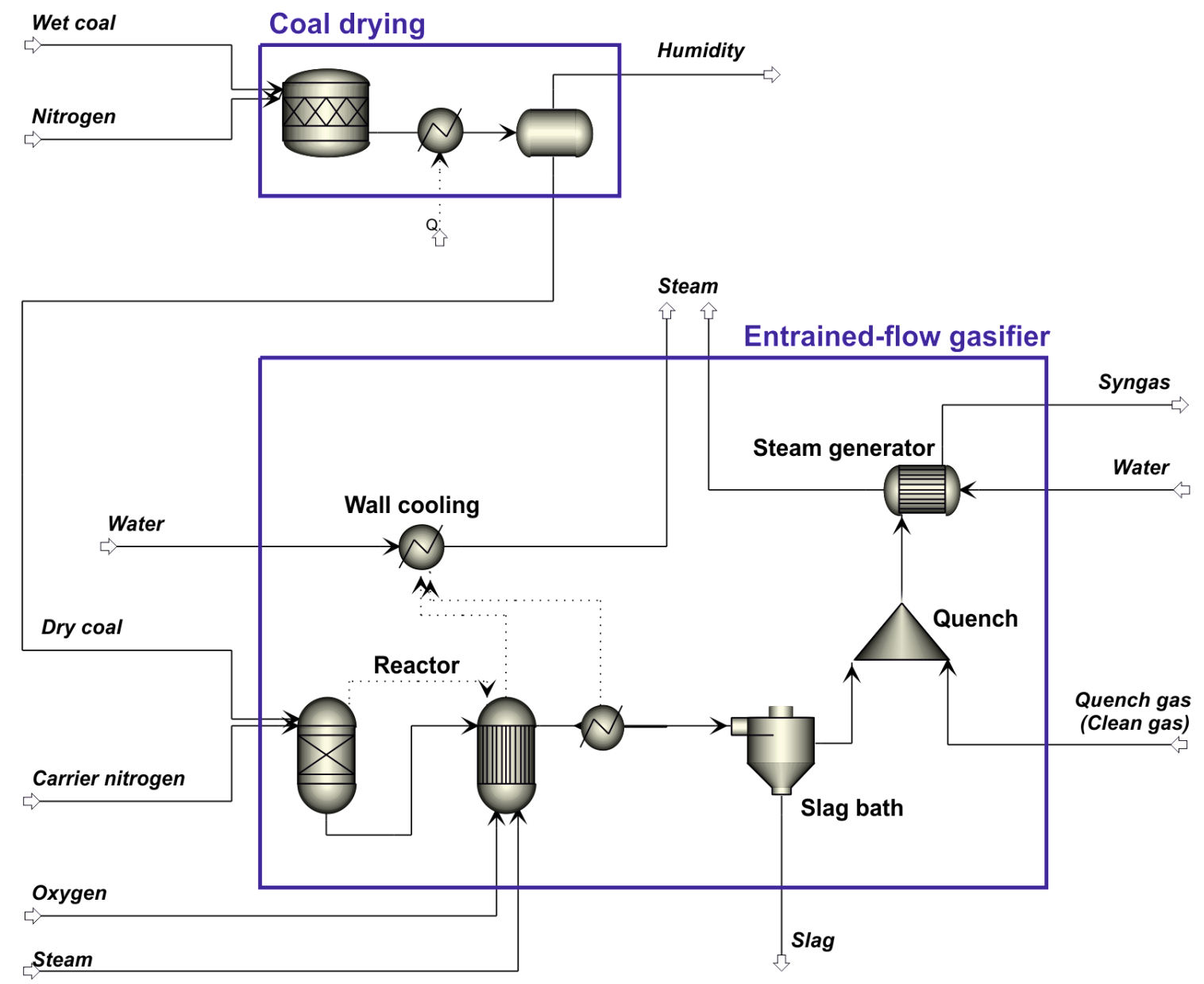

Figure 2. Simulation flowchart of Prenflo entrained-flow gasifier with upstream coal drying. 
For cooling of the reactor walls, medium pressure steam is generated in the Prenflo gasifier. The waste heat is about $7 \%$ of fuel heat input [38]. In Figure 2, this boundary condition is realized by the junction of two heat flows, namely the residual heat from the RGibbs-reactor and heat from a downstream Heater. Therefore, a feedback control system (Design Spec) is defined to vary the outlet temperature of the Heater to adjust this proportion of fuel heat input. At the same time, it will ensure that the gasification runs autothermically.

Table 3. Parameters of Applied Coals.

\begin{tabular}{|c|c|c|c|}
\hline & Unit & $\begin{array}{c}\text { Saar } \\
\text { Cl-arm }\end{array}$ & $\begin{array}{c}\text { Pittsburgh } \\
\text { No. } 8\end{array}$ \\
\hline $\begin{array}{c}\text { Ultimate analysis } \\
\text { Carbon }(\mathrm{C}) \\
\text { Hydrogen }(\mathrm{H}) \\
\text { Oxygen }(\mathrm{O}) \\
\text { Nitrogen }(\mathrm{N}) \\
\text { Sulfur }(\mathrm{S}) \\
\text { Chlorine }(\mathrm{Cl}) \\
\text { Ash }\end{array}$ & $\begin{array}{l}\text { wt } \% \text { (wf) } \\
\text { wt } \% \text { (wf) } \\
\text { wt } \% \text { (wf) } \\
\text { wt } \% \text { (wf) } \\
\text { wt } \% \text { (wf) } \\
\text { wt } \% \text { (wf) } \\
\text { wt } \% \text { (wf) }\end{array}$ & $\begin{array}{c}76.60 \\
5.00 \\
8.41^{*} \\
1.30 \\
1.02^{*} \\
0.17 \\
7.50\end{array}$ & $\begin{array}{c}76.43 \\
5.25 \\
5.87 \\
1.44 \\
3.16^{*} \\
0.06 \\
7.79\end{array}$ \\
\hline $\begin{array}{c}\text { Proximate analysis } \\
\text { Water } \\
\text { Fixed carbon } \\
\text { Volatile matter } \\
\text { Ash }\end{array}$ & $\begin{array}{c}\text { wt } \% \\
\text { wt } \% \text { (wf) } \\
\text { wt } \% \text { (wf) } \\
\text { wt } \% \text { (wf) }\end{array}$ & $\begin{array}{c}1.80 * * \\
57.20 * \\
35.30 \\
7.50\end{array}$ & $\begin{array}{c}5.50 \\
53.06^{*} \\
39.15 \\
7.79\end{array}$ \\
\hline $\begin{array}{l}\frac{\text { Thermophysical }}{\text { properties }} \\
\text { Gross calorific value } \\
\text { Net calorific value }\end{array}$ & $\begin{array}{l}\mathrm{kJ} / \mathrm{kg}(\mathrm{wf}) \\
\mathrm{kJ} / \mathrm{kg} \text { (wf) }\end{array}$ & $\begin{array}{c}31338 \\
30202 *\end{array}$ & $\begin{array}{l}32613 \\
31438\end{array}$ \\
\hline Literature source & & [9] & [39-41] \\
\hline
\end{tabular}

For simplified modeling of the slag bath, a multi-outlet component separator (Sep-separator) is used, where the overall amount of ash is separated. Hot syngas coming from reactor chamber is quenched in a stream mixer (Mixer) with colder clean gas. Mass flow of the clean gas is adjusted by a feedback control system (Design Spec) to get a quench outlet temperature of about $800{ }^{\circ} \mathrm{C}$. Downstream of the quench, there is a system for raw gas heat recovery installed, where saturated steam for a water/steam cycle is generated. Raw gas leaves the Prenflo gasifier with a temperature of about $400{ }^{\circ} \mathrm{C}$.

Modeling the recirculation of carried-out fly ash and coal particles is not appropriate at this level of detail.
Firstly, the energy demand for recirculation is negligible. Secondly, for the final mass balance it is irrelevant, because the fractions of ash and coal carried-out of the reactor have to be defined, but the degree of coal conversion including the recirculation is nearly 1 and $100 \%$ of the recirculated fly ash is lead out via the slag bath.

Table 4. Boundary Conditions of the Prenflo Gasifier Experiments Published in [9].

\begin{tabular}{l|c|c|c|c|c}
\hline \multicolumn{1}{c|}{ Value } & Unit & Design & $\begin{array}{c}\text { Run } \\
\text { A }\end{array}$ & $\begin{array}{c}\text { Run } \\
\text { B }\end{array}$ & $\begin{array}{c}\text { Run } \\
\text { C }\end{array}$ \\
\hline Pressure & bar & 30 & 24 & 24 & 24 \\
$\mathrm{O}_{2}$-purity & vol \% & 99.9 & 99.5 & 85 & 98.6 \\
$\mathrm{O}_{2} /$ coal & $\mathrm{kg} / \mathrm{kg}$ (waf) & 0.99 & 1.01 & 1.05 & 1.03 \\
Steam/coal & $\mathrm{kg} / \mathrm{kg}$ (waf) & 0.05 & & & 0.06 \\
\hline
\end{tabular}

\section{Model Validation}

The overall model of the Prenflo gasifier was compared with operating data of a demonstration plant in Fürstenhausen (Germany) [9]. As the feed coal the bituminous coal named "Saar Cl-arm" with the fuel parameters listed in Table 3 is used. The studies published in [9] include an experiment under rated operating conditions ("Design") and three experiments at reduced pressure with various mixtures of gasifying agents ("Run A", "Run B", "Run C"), see Table 4.

Since some values of necessary operating conditions are missing in the literature source, the following further assumptions are set for the planned comparison, which are not discussed in Chapter 5. These data are taken from IGCC of Puertollano (Spain) [36] or derived from simulation results of an air separation unit under these conditions:

- State of input streams is defined as follows:

- Steam: The pressure is 35 bar [36] with steam content of $99.9 \%$.

- Technical oxygen: The pressure is 31 bar [36] and temperature is $280{ }^{\circ} \mathrm{C}$.

- Carrier nitrogen: The pressure is 49 bar [36] and temperature is $400{ }^{\circ} \mathrm{C}$.

- Technical oxygen and carrier nitrogen are not pure substances. Technical oxygen contains small amounts of nitrogen and argon and carrier nitrogen has small quantities of oxygen and argon. These are put into a mole ratio of about $108: 1$..

- The temperature of gasification is $1500^{\circ} \mathrm{C}$ [38].

Table 5. Comparison between Operating Data According to [9] and Results from the Simulation of the Prenflo Coal Gasifier.

\begin{tabular}{|c|c|c|c|c|c|c|c|c|c|}
\hline \multirow{2}{*}{ Value } & \multirow{2}{*}{ Unit } & \multicolumn{2}{|c|}{ Design } & \multicolumn{2}{|c|}{ Run A } & \multicolumn{2}{|c|}{ Run B } & \multicolumn{2}{|c|}{ Run C } \\
\hline & & Operation & Model & Operation & Model & Operation & Model & Operation & Model \\
\hline$\underline{\text { Raw gas analysis }}$ & & & & & & & & & \\
\hline $\mathrm{CO}$ & vol \% (wf) & 65.8 & 66.6 & 68 & 68.3 & 62.8 & 65.6 & 64.9 & 66.0 \\
\hline & vol \% (wf) & 27.3 & 28.2 & 26.8 & 26.9 & 24.7 & 24.8 & 27.8 & 27.2 \\
\hline $\mathrm{N}_{2}+\mathrm{Ar}$ & vol \% (wf) & 4.5 & 3.8 & 4.6 & 4.0 & 10.4 & 7.8 & 4.4 & 4.2 \\
\hline $\mathrm{CO}_{2}$ & vol \% (wf) & 2.3 & 1.0 & 0.4 & 0.4 & 1.8 & 1.4 & 2.6 & 2.2 \\
\hline $\mathrm{H}_{2} \mathrm{~S}+\mathrm{CU}_{2}$ & vol \% (wf) & 0.2 & 0.3 & 0.2 & 0.7 & 0.3 & 0.2 & 0.3 & 0.1 \\
\hline$\left(\mathrm{CO}+\mathrm{H}_{2}\right) /$ coal & $\mathrm{m}^{3} / \mathrm{kg}$ (waf) & 2.05 & 2.17 & 2.12 & 2.14 & 2.06 & 2.08 & 2.11 & 2.11 \\
\hline Cold gas efficiency & $\%$ & 77.6 & 80.8 & 79.9 & 79.9 & 77.6 & 77.9 & 79.6 & 78.8 \\
\hline
\end{tabular}


The comparison between operating data and simulation results is listed in Table 5. For all parameters, the calculated values of the model reproduce the operating data fairly precisely. This is particularly true for the cold gas efficiency and the main components of the raw gas: carbon monoxide and hydrogen. Slight differences in the case of the inert and pollutant components exist. This is acceptable because they are energetically irrelevant and not in the focus of this work. The created model for the Prenflo gasification process is hereby validated and can be used in planned power plant simulations under similar operating conditions, e.g. IGCC or hybrid power plants. Also, since the model is based on the unmodified Gibbs energy minimization method, the usage in other applications and/or under different operating conditions might be possible and deliver accurate results.

\section{Parametric Study for a Target Application}

The described model of the coal gasifier is qualified by extensive parameter variations regarding operating parameters such as pressure and temperature of gasification and mass flow ratios of the gasifying agents to coal. Also, different types of feed coal can be used, but such variation is more interesting for complete system simulations. For the parametric study, the bituminous coal named "Pittsburgh No. 8" with the fuel parameters listed in Table 3 is used as the feed coal. Furthermore, boundary conditions are set as they are in the power plants to be simulated later: The coal is dried until water content falls below $2 \%$, then gasified with $85 \%$-pure oxygen and steam at the mass flow ratios of the gasifying agent to coal, defined in Chapter 5 under an operating pressure of 25 bar and a gasification temperature of $1500{ }^{\circ} \mathrm{C}$. Gasifying agents are added at pressures and temperatures specified in Chapter 6. These figures are fixed in all cases except the parameter varied in the discussed case.

\subsection{Pressure and Temperature}

When the final application is IGCC and hybrid power plants, the gasification pressure is set by a given pressure ratio of the gas turbine and resulting pressure losses of gas cleaning stages (Korobov, 2003). For this reason, only the influence of the gasification temperature level on raw gas composition and on cold gas efficiency will be discussed here in more detail.

In Figure 3, the resulting raw gas composition is plotted cumulatively and in Figure 4, the calculated cold gas efficiency resulting from Eq. (2) is shown, both as a function of gasification temperature and the latter additionally for various gasification pressures. The chosen temperature range between 800 and $1500{ }^{\circ} \mathrm{C}$ corresponds to other publications based on equilibrium models ([15], [26], [27]). The different raw gas compositions at various temperatures are caused by different equilibrium positions of the chemical reactions listed in Tables 1 and 2. Equilibria of endothermic reactions $\left(\Delta^{R} H>0\right)$ shift with increasing temperature to the products, whereas equilibria of exothermic reactions $\left(\Delta^{R} H<0\right)$ shift to the reactants. Figure 3 shows that the raw gas composition changes significantly with increasing gasification temperature between 800 and $1000{ }^{\circ} \mathrm{C}$. Otherwise, the resulting raw gas composition is almost constant above $1000{ }^{\circ} \mathrm{C}$. In practice, gasification temperatures considerably higher than $1000^{\circ} \mathrm{C}$ are common. This is due to higher reaction rates and thereby smaller sizes of gasifiers, and not due to any advantageous raw gas composition. At the reference temperature of $1500{ }^{\circ} \mathrm{C}$ the raw gas composition is $55.8 \%$ $\mathrm{CO}, 25.8 \% \mathrm{H}_{2}, 3.8 \% \mathrm{CO}_{2}, 6.4 \% \mathrm{H}_{2} \mathrm{O}$ and $8.2 \%$ rest.

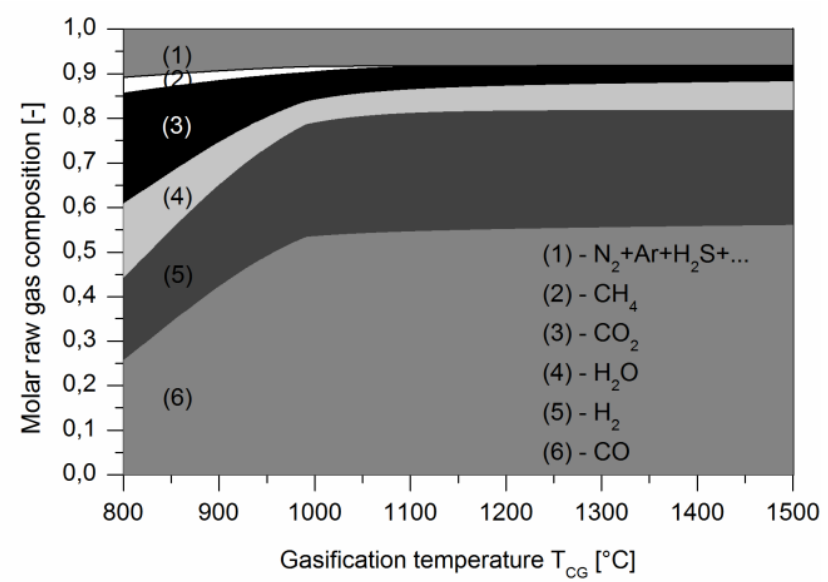

Figure 3. Raw gas composition as a function of gasification temperature.

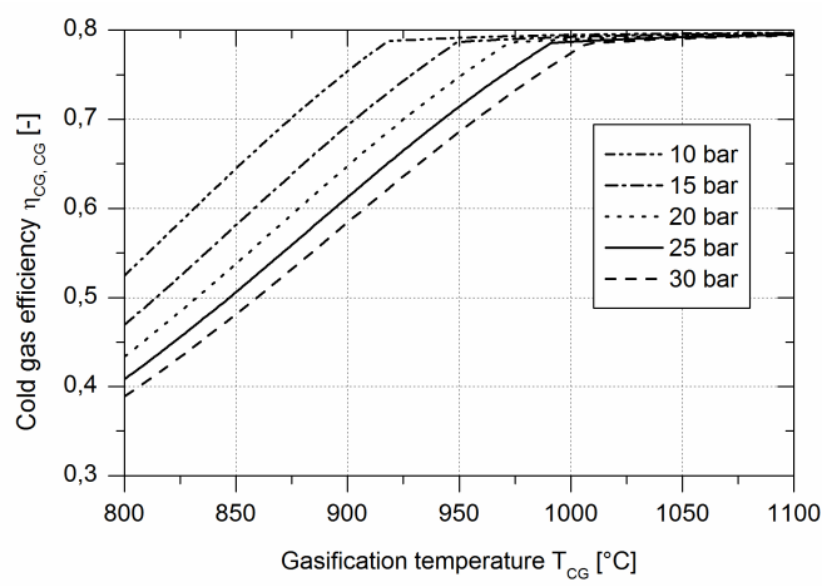

Figure 4. Cold gas efficiency as a function of gasification temperature for various gasification pressures.

Correspondingly, dependences are clarified by a trend of cold gas efficiency at 25 bar as a function of gasification temperature. Increasing the gasification temperature from $800{ }^{\circ} \mathrm{C}$ to approx. $1000{ }^{\circ} \mathrm{C}$ results in nearly doubling the figure of cold gas efficiency from approx. 0.4 to 0.78 , whereas the dependence is almost linear. Above $1000{ }^{\circ} \mathrm{C}$, the cold gas efficiency increases slowly and asymptotically approaching 0.8 - according to [6], the maximum possible value for the cold gas efficiency. At lower pressures of gasification, the maximum possible value of cold gas efficiency is reached at lower temperatures. Furthermore, it is visible that the lower the pressure, the higher is the resulting cold gas efficiency of the process. This is evident when looking at the set of key reactions chosen in Chapter 5. According to Le Chatelier's principle, the hydrogasification reaction in Table 1 is promoted at higher pressures and a heterogeneous water gas reaction is promoted at lower pressures, while the other key reactions, namely partial combustion and a homogeneous water gas reaction are not influenced directly. Therefore, the higher the pressure, the higher is the content of methane and steam and the lower is the content of carbon monoxide and hydrogen. The favored reactions at high pressures are exothermic. That is why the maximum possible value of cold gas efficiency is reached at lower temperatures. At temperatures appreciably higher than $1000{ }^{\circ} \mathrm{C}$, the raw gas 
composition and the cold gas efficiency is mostly independent from the pressure in the range considered here. This is consistent with results from [29]. Higman \& van der Burgt [6] also published parametric studies regarding temperature and pressure. The results are similar in tendency but not in the actual value due to the fact that not all of the boundary conditions are published by the authors.

\subsection{Mass Flow Ratios of Gasifying Agents to Coal}

In this section, the sensitivity of raw gas composition and cold gas efficiency to the mass flow ratios of the gasifying agents, oxygen and steam, to coal are analyzed. In Figures 5 and 6 , the results of the variation of oxygen-tocoal mass flow ratio are shown. Considering the waste heat fixed in Chapter 5, the gasifier works not autothermically but allothermically below a ratio of approx. 1, which means that the energy has to be supplied to the system from the outside. The maximum value of the cold gas efficiency is about 0.884 . Above this value, more oxygen leads to lower contents of the combustible components hydrogen and carbon monoxide and to higher contents of combustion products carbon dioxide and water.

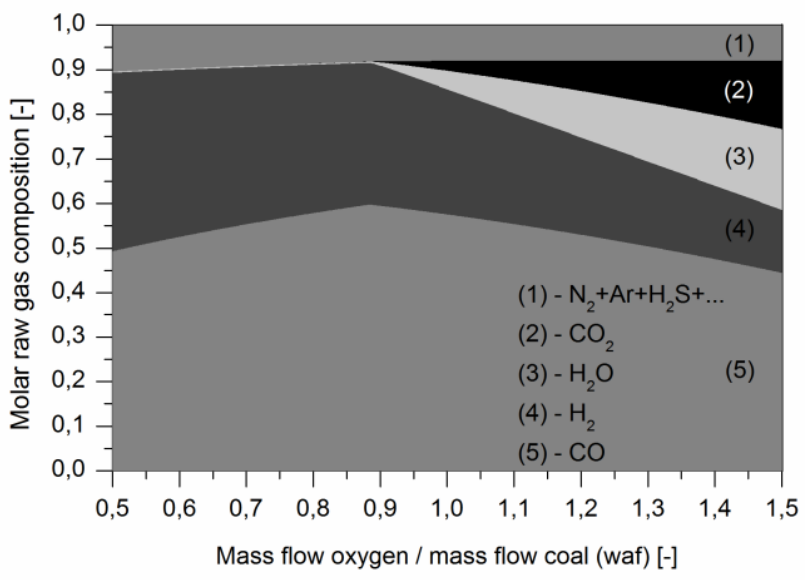

Figure 5. Raw gas composition as a function of oxygen-tocoal mass flow ratio.

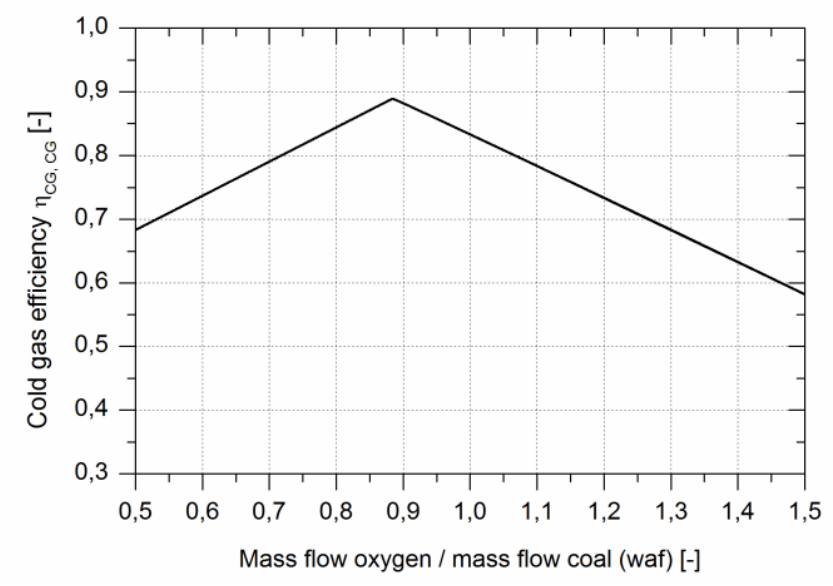

Figure 6. Cold gas efficiency as a function of oxygen-tocoal mass flow ratio.

In Figure 7, the results of the variation of steam-to-coal mass flow ratio regarding the raw gas composition are shown. While the percentage of hydrogen is more or less constant at a value around $25 \%$, the content of carbon monoxide decreases from $63 \%$ to $44 \%$ and more water and carbon dioxide is produced. This is evident when looking at the set of key reactions chosen in Chapter 5.
According to Le Chatelier's principle, both water gas reactions in Table 1 are promoted at higher steam contents, while the other key reactions, namely partial combustion and hydrogasification, are not influenced directly. The cold gas efficiency is mostly independent from the steam-to-coal mass flow ratio in the range considered here, because the increasing mass flow caused by additional steam nearly compensates the lower content of carbon monoxide.

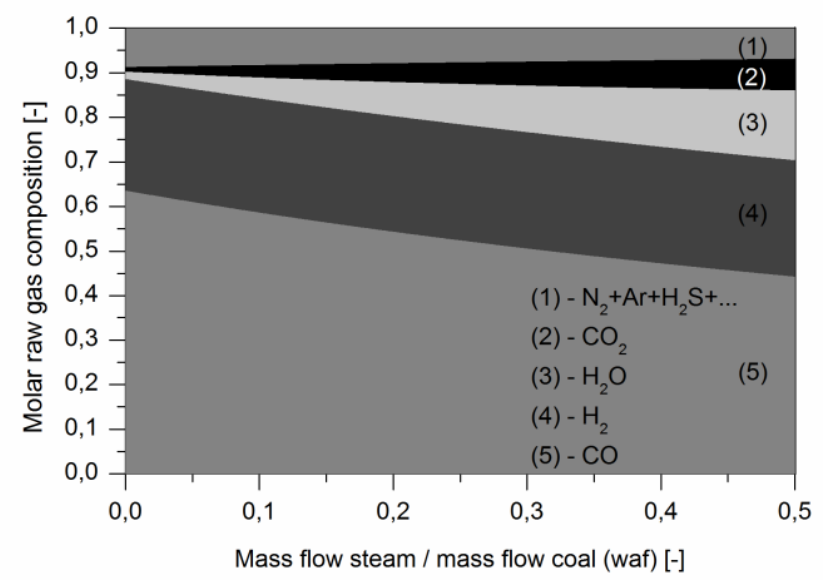

Figure 7. Raw gas composition as a function of steam-tocoal mass flow ratio.

\section{Summary and Conclusions}

In order to simulate complex power plants with integrated coal gasification as in IGCC and hybrid power plants, simplified process models are needed. In this article, a model for an entrained-flow coal gasifier, the Prenflo coal gasification process, is developed. It is an equilibrium model, utilizing various built-in components of the applied process simulation software.

The elaborated model is compared with operating data of a demonstration plant in Fürstenhausen (Germany) published in literature. For all parameters, the calculated values of the model reproduce the operating data fairly precisely. Therefore, the elaborated model for the Prenflo gasification process is validated.

Extensive parametric study was performed. The results of these studies regarding variations of the temperature and pressure of gasification as well as the mass flow ratios of gasifying agents to coal are presented here. Out of it follows that sensitivity of product gas composition and of cold gas efficiency to temperature changes is strong in the range $800{ }^{\circ} \mathrm{C}$ to approx. $1000{ }^{\circ} \mathrm{C}$; at higher temperatures, the influence of temperature and pressure is limited. The sensitivity study regarding the mass flow ratio of the gasifying agent oxygen to coal shows that the gasifier works autothermically above an oxygen-to-coal ratio of approx. 1 and the maximum value of the cold gas efficiency is about 0.884 . The variation of the steam-to-coal mass flow ratio results in a more or less constant percentage of hydrogen of about $25 \%$, while the content of carbon monoxide decreases and the content of water and carbon dioxide increases. The cold gas efficiency is mostly independent from the steam-to-coal mass flow ratio in the range considered.

The described model of the coal gasifier is qualified for implementation in system models such as those of hybrid power plants including high temperature fuel cells. 


\section{Nomenclature}

$h \quad$ Specific enthalpy $[\mathrm{kJ} / \mathrm{kg}]$

$N C V \quad$ Net calorific value $[\mathrm{kJ} / \mathrm{kg}]$

$\dot{m} \quad$ Mass flow $[\mathrm{kg} / \mathrm{s}]$

$\dot{Q} \quad$ Heat flow $[\mathrm{kW}]$

$T \quad$ Temperature $\left[{ }^{\circ} \mathrm{C}\right]$

$w \quad$ Mass fraction

$\Delta^{R} H \quad$ Enthalpy of reaction $[\mathrm{kJ} / \mathrm{mol}]$

$\eta \quad$ Degree or efficiency

Indices:

C Coal, carbon

$C G \quad$ Coal gasifier, cold gas

$G A \quad$ Gasifying agent

$R G \quad$ Raw gas

th Thermal

Acronyms:

IGCC Integrated gasification combined cycle

IGFC Integrated gasification fuel cell

Prenflo Pressurised entrained flow

waf Water ash free

wf Water free

\section{References}

[1] M. Krüger, "Process Development for Integrated Coal Gasification SOFC Hybrid Power Plants," in International Conference on Energy Process Engineering, Dechema, Frankfurt am Main, Germany, 2011.

[2] M. Krüger, Verfahrensentwicklung für SOFCHybridkraftwerke mit Integrierter Kohlevergasun, (Ph.D. dissertation), University of Stuttgart, Germany, 2013. ISBN 978-3-8439-0887-0.

[3] A. G. Collot, "Matching Gasifiers to Coals," CCC / IEA Coal Research, no. 65, IEA Coal Research, The Clean Coal Centre, London, 2002.

[4] B. Meyer, "Prozesse mit integrierter Kohlevergasung," Fortschrittliche Braunkohlenutzung im liberalisierten Strommarkt, VDI-Berichte 1456, Düsseldorf: VDIVerlag, 1999.

[5] R. Kloster, "Thermodynamische Analyse und Optimierung von Gas-/Dampfturbinen-KombiKraftwerken mit integrierter Kohlevergasung," Fortschritt-Berichte VDI Reihe 6, no. 409, Düsseldorf: VDI-Verlag, 1999.

[6] C. Higman, M. van der Burgt, Gasification, Oxford: Elsevier, 2003.

[7] R. Wetzel, "Kohledruckvergasung (PRENFLOVerfahren)," Schlussbericht: Förderungsvorhaben BMFT, Förderkennzeichen: $0326211 \quad \mathrm{~F} / \mathrm{G} / \mathrm{H}$, Bundesministerium für Forschung und Technologie (BMFT), Bonn, Germany, 1993.

[8] H. C. Pohl, W. Schellberg, "PRENFLO: Das Verfahren zur Flugstrom- Druckvergasung," Technische Mitteilungen Krupp, 1987 (2).

[9] R. Wetzel, Prenflo - Ein Beitrag zur effizienten, umweltfreundlichen Kohleverstromung, Technische Mitteilungen, 83, 33-38, 1990.
[10] DTI, "Gasification of solid and liquid fuels for power generation," Technology Status Report TSR, no. 008, Department of Trade \& Industry (DTI), London, U.K., 1998.

[11] R. E. Wetzel, "The Krupp Koppers Prenflo Process for Coal Gasification," Progress in synthetic fuels: Proceedings of the First Contractors' Meeting on the Results of the Subprogramme "Production and Utilization of New Energy Vectors," European Commision, Saarbrücken, 1988.

[12] W. Schellberg, "Combined cycle (IGCC) with prenflo and its contribution to reducing greenhouse gas emissions," International Conference on Coal, the Environment and Development: Technologies to Reduce Greenhouse Gas Emissions. International Energy Agency, Organisation for Economic Co-operation and Development, Sydney, 1991.

[13] H. Hiller, "Gas Production," Bailey, J. (Ed.), Ullmann's Encyclopedia of Industrial Chemistry, Weinheim: Wiley-VCH, 2005.

[14] B. Meyer, D. Korobov, "55\%-IGCC-Kraftwerk," Schlussbericht zum BMWA-Forschungsvorhaben, Förderkennzeichen: 0327117, Bundesministerium für Wirtschaft und Arbeit (BMWA), Berlin, 2006.

[15] G. Tsatsaronis, J. Janicka, Anwendbarkeit von Gleichgewichtsmodellen zur Simulation von Kohlevergasungsreaktoren, Erdöl und Kohle, Erdgas, Petrochemie. 35, 337-341, 1982.

[16] W. Schmitz, J. Karl, D. Hein, "Kreislaufrechnungen zur Stromerzeugung aus biomassestämmigem Brenngas: Modellierung - Ergebnisse - energetische Bewertung integrierter Prozesse," Beiträge zur DGMK-Fachbereichstagung "Energetische und stoffliche Nutzung von Abfällen und Biomassen", Deutsche Wissenschaftliche Gesellschaft für Erdöl, Erdgas und Kohle e. V., Velen, Germany, 2000.

[17] K. K. Neumann, F. Keil, Thermodynamische Berechnungen $\mathrm{zu}$ Kohlevergasungsprozessen, Brennstoff, Wärme, Kraft: BWK. 33, 22-25, 1981.

[18] R. Wessel, “Thermodynamische Analyse kombinierter Gas-Dampf-Kraftwerke mit integrierter Kohlevergasung," Fortschritt-Berichte VDI Reihe 6, no. 240, Düsseldorf: VDI-Verlag, 1990.

[19] D. Boeddicker, "Thermodynamische und energiewirtschaftliche Bewertung eines KombiKraftwerks mit integrierter Kohlevergasung und $\mathrm{CO}_{2}-$ Rezyklierung," Fortschritt-Berichte VDI Reihe 6, no. 368, Düsseldorf: VDI-Verlag, 1997.

[20] V. Brand, "Rückhaltung von Kohlendioxid in Kombikraftwerken mit integrierter Kohlevergasung," Fortschritt-Berichte VDI Reihe 6, no. 350, Düsseldorf: VDI-Verlag, 1996.

[21] G. Göttlicher, "Energetik der Kohlendioxidrückhaltung in Kraftwerken," Fortschritt-Berichte VDI Reihe 6, no. 421, Düsseldorf: VDI-Verlag, 1999.

[22] Y. Zhu, Evaluation of Gas Turbine and Gasifier-based Power Generation System, (Ph.D. dissertation), North Carolina State University, USA, 2004. 
[23] T. Kivisaari, P. Björnbom, C. Sylwan, B. Jacquinot, D. Jansen, A. de Groot, The Feasibility of a Coal Gasifier Combined with a Hightemperature Fuel Cell, Chemical Engineering Journal, 100, 167-180, 2004.

[24] A. Lokurlu, "Simulation der Oxidkeramischen Brennstoffzelle "SOFC" mit nachgeschalteten Gas- und Dampfturbinen-Kombi-Anlagen für verschiedene Brenngase," Fortschritt-Berichte VDI Reihe 6, no. 425, Düsseldorf: VDI-Verlag, 1999.

[25] S. Li, "Thermodynamic Analysis of Natural Gas and Coal Fuelled Humid Air Turbine Cycles," FortschrittBerichte VDI Reihe 6, no. 481, Düsseldorf: VDIVerlag, 2002.

[26] G. Kovacik, M. Oguztöreli, A. Chambers, B. Özüm, Equilibrium calculations in coal gasification. Int. J. Hydrogen Energy, 15, 125-131, 1990.

[27] C. R. Altafini, A. Mirandola, "A Chemical Equilibrium Model of the Coal Gasification Process Based on the Minimization of the Gibbs Free Energy," Flowers '97: Florence World Energy Research Symposium: "Clean Energy for the New Century", Dipartimento di Energetica "Sergio Stecco"; Universita degli Studi di Firenze, Florence, Italy, 1997.

[28] B. Zaporowski, "Modelling and Simulation of the Process of Coal Gasification," Gasification for the Future, Noordwijk, The Netherlands, 2000.

[29] Q. Ni, A. Williams, A Simulation Study on the Performance of an Entrained-flow Coal Gasifier, Fuel. 74, 102-110, 1995.

[30] G. Manfrida, G. Bidini, G. Trebbi, "Modeling Coal Gasification Combined Cycles (CGCC)," A future for energy: Flowers '90; Proceedings of the Florence Worlds Energy Research Symposium, Florence World Energy Research Symposium, Florence, Italy, 1990.

[31] P. Schoen, Dynamic Modeling and Control of Integrated Coal Gasification Combined Cycle Units. (Ph.D. dissertation), Techn. Universiteit Delft, Netherlands, 1993.

[32] H. Jüntgen, K. H. van Heek, Kohlevergasung: Grundlagen und technische Anwendung, München: Thiemig, 1981.

[33] Müller-Erlwein, E., Chemische Reaktionstechnik, Stuttgart: Teubner, 1998.
[34] Aspen Technology, Inc., Aspen Plus: Reference Manuals, Version Number: 2006.5, Cambridge, USA, 2007.

[35] D. Korobov, "Untersuchung der Wirkungsgradpotentiale von IGCC-Kraftwerkskonzepte,". Freiberger Forschungshefte Reihe A: Energie, no. 876, Technische Universität Bergakademie Freiberg, 2003.

[36] M. Trevino Coca, "Integrated Gasification Combined Cycle Technology: IGCC: Its Actual Application in Spain: ELCOGAS, Puertollano," ELCOGAS, S.A.; Club Espanol de la Energia, 2003.

[37] B. Orlandi, Beitrag zur Implementierung eines neuartigen IGCC/SOFCKraftwerksprozesses in Aspen Plus. (student research project), Institute for Technical Thermodynamics, German Aerospace Center, Stuttgart; Institute for Thermodynamics and Thermal Engineering, Stuttgart University, Germany, 2006.

[38] R. Pruschek, G. Oeljeklaus, G. Haupt, G., Zimmermann, Überblick über wirkungsgradsteigernde Maßnahmen bei Kombiprozessen und Verbesserungspotentiale von Kraftwerken mit integrierter Kohlevergasung (IGCC) - Wirkungsgrad, Kostenwirksamkeit und Verfügbarkeit. Entwicklungslinien der Energie- und Kraftwerkstechnik, VDI-Berichte 1280, Düsseldorf: VDI-Verlag, 1996.

[39] G. Haupt, G. Zimmermann, H. R. Baumann, N. Ullrich, R. Pruschek, G. Oeljeklaus, "New Design of IGCC for Competitive Power Generation," Gasification Technologies Conference, Gasification Technologies Council, San Francisco, USA, 1998.

[40] G. Haupt, G. Zimmermann, R. Pruschek, G. Oeljeklaus, N. Ullrich, "Modern IGCC Stations as High-Effective Means for $\mathrm{CO}_{2}$ Reduction," 5th International Conference on Greenhouse Gas Control Technologies, Cairns, Australia, 2000.

[41] R. Pruschek, D. Jansen, R. van Ree, R., Korbee, R. P. de Smidt, B. C. Williams, "Advanced Cycle Technologies: Improvement of IGCCs Starting from the State-of-the-Art (Puertollano)," ECN-RX, no. 98-063, Netherlands Energy Research Foundation (ECN), Petten, Netherlands, 1998. 